\title{
MODEL PEMBERDAYAAN IBU BALITA TENTANG MP-ASI DI KELURAHAN WONOREJO KABUPATEN KARANGANYAR
}

\section{Mother Empowerment Model for Toddler About MP ASI in Wonorejo Village Karanganyar District}

\author{
Fresthy Astrika Yunita'), Hardiningsih'), Agus Eka Nurma Yuneta ${ }^{3)}$ \\ *Jurusan Kebidanan, Fakultas Kedokteran, Universitas Sebelas Maret \\ Jl. Ir. Sutami 36A Kentingan, Jebres Surakarta 57126 telp. (0271) 662622 \\ E-mail:fresh_outside@yahoo.com
}

\begin{abstract}
ABSTRAK
Latar belakang: Lima tahun pertama usia emas seorang anak (Golden Age) adalah masa yang sangat menentukan. Makanan pendamping ASI perlu di berikan balita usia 6 bulan, ASI bagi bayi tidak lagi mencukupi kebutuhan energi untuk tumbuh dan berkembang, tetapi selama pemberian makanan tambahan pada bayi ASI tetap di berikan pada balita. Masalah kesehatan dan sosial yang dihadapi Indonesia adalah rendahnya status gizi masyarakat Status Gizi balita menurut Rikesdas 2013 adalah 5,7\% gizi buruk dan 13,9 \% gizi kurang. Tujuan pengabdian masyarakat ini adalah untuk melaksanakan model pemberdayaan pada Ibu Balita tentang MP ASI di Kelurahan Wonorejo sehingga diharapkan ibu balita mampu mengembangkan pola asuh tentang pengetahuan Makanan Pendamping ASI.

Subjek dan Metode: Model pemberdayaan ibu balita tentang MP ASI ini dilakukan melalui koordinasi Bidan Koordinator di PKD kelurahan Wonorejo, kader dan personil yang terlibat dalam kegiatan posyandu untuk selanjutnya melakukan penyuluhan kepada ibu balita.

Hasil: Hasil pengabdian adalah telah dilaksanakan pemberdayaan MP ASI pada ibu balita di kelurahan wonorejo. Ibu balita mendapatkan pengetahuan tentang MP ASI dan beberapa contoh pengolahan menu MP ASI yang dapat diterapkan dirumah.

Kesimpulan: Diharapkan balita mendapatkan gizi yang cukup dengan penerapan MP ASI sesuai dengan tahapannya sehingga proses tumbuh kembang berjalan dengan baik dan normal sesuai perkembangan umurnya.
\end{abstract}

Kata kunci: Pemberdayaan, ibu balita, MPASI 


\begin{abstract}
Background: The first five years of a child's golden age (Golden Age) is a very decisive time. MP ASI need to be given to 6-month-old toddlers, A breast milk is no longer complete the energy needs for growth, but during giving an addition food to infant, breastmilk must be given to them. The health and social problems faced by Indonesia are the low nutritional status of children under five. According to the 2013 Rikesdas Nutrition Status $5.7 \%$ malnutrition and $13.9 \%$ less nutrition. The purpose of this community service is to implement the empowerment model for Mother with toddler about MP ASI in Wonorejo Village so that mothers of children under five are expected to be able to develop the knowledge of upbringing about complementary foods.

Subjects and Method: The model of empowering mothers with children under five about MP ASI was conducted through the coordination of the Coordinating Midwife in the Wonorejo village PKD, cadres and personnel involved in the posyandu activities to then provide counseling to the mothers of children under five.

Results: The result of dedication is that MP ASI empowerment has been carried out for mothers of children under five in Wonorejo village. Mothers with children under five get knowledge about MP ASI and some examples of processing MP ASI menus that can be applied at home.

Conclusion: It is expected that toddlers get adequate nutrition by applying MP ASI according to the stages so that the growth process goes well and normal according to their age.
\end{abstract}

Keywords: Empowerment, mothers of children under five, MPASI

\section{PENDAHULUAN}

$\overline{\text { Kesejahteraan masyarakat menurut United }}$ Nations Development Program (UNDP) diukur oleh Indeks Pembangunan Manusia (IPM) atau Human Development Index (HDI). IPM merupakan indikator komposit dari tiga indikator sektor pembangunan, yaitu pendidikan, kesehatan, dan ekonomi. Indikator kesehatan dipergunakan untuk menentukan hidup sehat dan panjang umur, diukur dengan Angka Harapan Hidup (AHH), dihitung dari Angka Kematian Bayi (AKB). Berdasarkan Laporan Pembangunan Manusia (2015) Indeks Pembangunan Manusia (IPM) Indonesia berada di peringkat ke-110 dari 188 negara dengan besaran 0,684 atau sama dengan tahun sebelumnya. Fakta ini menunjukkan makin merosotnya kualitas hidup manusia Indonesia (UNDP, 2015) ${ }^{(1)}$.

Tujuan pembangunan millennium (Millennium Development Goals, MDGs) 2000-2015 dilanjutkan dengan tujuan pembangunan berkelanjutan (Sustainable Development Goals, SDGs) 2016-2030 dengan 17 tujuan dan 169 target. Tiga tujuan SDGs terkait dengan kemiskinan, kelaparan, ketahanan pangan, peningkatan gizi, serta hidup sehat dan kesejahteraan. Tujuan pertama SDGs adalah mengakhiri kemiskinan dalam segala bentuknya dimanapun; Tujuan kedua SDGs adalah mengakhiri kelaparan, mencapai ketahanan pangan dan meningkatkan gizi, serta mendorong pertanian yang berkelanjutan; dan tujuan ketiga adalah pastikan hidup sehat dan mempromosikan kesejahteraan untuk semua pada segala usia (UNDP, 2015) ${ }^{(1)}$.

Pemberian Makanan Pendamping ASI sebagai upaya pencapaian tujuan kedua SDGs. Menurut WHO $(2001)^{(2)}$ memberikan Makanan Pendamping Air Susu Ibu (MP-ASI) sejak bayi berusia 6 bulan sampai 24 bulan. MP-ASI hendaknya dibuat dari bahan pangan yang murah dan mudah diperoleh di daerah setempat.

Survei Demografi dan Kesehatan Indonesia (SDKI, 2012) ${ }^{(2)}$ menunjukkan bahwa AKB turun perlahan dari $142 \mathrm{ke}-$ matian per 1.000 kelahiran hidup $(\mathrm{KH})$ di tahun 1967 menjadi 32 kematian per 
1.000 KH di tahun 2012. Dalam rangka menurunkan angka kesakitan dan kematian anak, United Nation Childrens Fund (UNICEF) dan World Health Organization (WHO) merekomendasikan pemberian ASI Eksklusif 6 bulan pertama kehidupan dan dilanjutkan dengan pengenalan MP-ASI sampai usia 2 tahun.

Masalah gizi yang banyak terjadi di Indonesia sebagai negara berkembang saat ini yaitu gizi kurang, pendek, dan kurus. Secara nasional, berdasarkan riset kesehatan dasar 2013, prevalensi stunting nasional mencapai $37,2 \%$ yang terdiri dari $18,0 \%$ anak sangat pendek dan 19,2\% anak pendek, meningkat dari tahun 2010 $(35,6 \%)$ dan 2007 (36,8\%). Prevalensi balita stunting di Provinsi Daerah Istimewa Yogyakarta (DIY) lebih rendah daripada angka nasional yaitu $28,5 \%$ (3). Senada dengan data ini, Depertemen kesehatan kabupaten Karanganyar mengatakan Pada tahun 2014 di Kabupaten Karanganyar terdapat $6,8 \%$ balita kekurangan gizi.

MP-ASI merupakan proses transisi dari asupan yang semata berbasis susu menuju ke makanan yang semi padat. Pengenalan dan pemberian MP-ASI harus dilakukan secara bertahap baik bentuk maupun jumlahnya, sesuai dengan kemampuan pencernaan bayi/anak. Pemberian MP-ASI yang tepat diharapkan tidak hanya dapat memenuhi kebutuuhan gizi bayi, namun juga merangsang keterampilan makan dan merangsang rasa percaya diri pada bayi. Pemberian makanan tambahan harus bervariasi dari bentuk bubur cair kebentuk bubur kental, sari buah, buah segar, makanan lumat, makanan lembek dan akhirnya makanan padat.

Tujuan pemberian MP-ASI adalah untuk menambah energi dan zat-zat gizi yang diperlukan bayi karena ASI tidak dapat memenuhi kebutuhan bayi secara terus menerus, dengan demikian makanan tambahan diberikan untuk mengisi kesenjangan antara kebutuhan nutrisi total pada anak dengan jumlah yang didapatkan dari ASI.
Masalah gizi secara garis besar disebabkan oleh dua faktor yaitu faktor langsung dan faktor tidak langsung. Faktor langsung yang mempengaruhi status gizi adalah asupan makanan (energi dan protein) danpenyakit penyerta (infeksi). Sedangkan faktor tidak langsung adalah tingkat pengetahuan, tingkat pendidikan, tingkat pendapatan, pola asuh, sosial budaya, ketersediaan pangan, pelayanan kesehatan dan faktor lingkungan

Menghadapi keadaan ini, peran orang tua yang langsung mengasuh balita, di perlukan pola pembinaan yang arif dan variatif kepada orang tua asuh pembuatan makanan pendamping ASI (MP-ASI).

Berdasarkan studi pendahuluan yang telah dilakukan di Kabupaten karanganyar, persoalan gizi kurang di Kabupaten Karanganyar dipengaruhi oleh beberapa faktor, ada dua penyebab, yaitu karena sakit dan karena kurang asupan gizi, yang perlu di ubah pada kurang asupan gizi pada anak balita sebagian besar disebabkan oleh pola asuh orang tua. Dengan melihat fenomena tersebut kami bermaksud mengadakan pemberdayaan ibu balita tentang MP ASI agar diharapkan meningkatkan cakupan gizi pada bayi dan balita.

Tujuan dari kegiatan ini adalah untuk melaksanakan model pemberdayaan pada ibu balita tentang MP ASI di Kelurahan Wonorejo Kabupaten Karanganyar sehingga diharapkan ibu balita mampu mengembangkan pola asuh tentang pengetahuan makanan pendamping ASI. Manfaat dari kegiatan model pemberdayaan pada ibu balita tentang MP ASI di Kelurahan Wonorejo Kabupaten Karanganyar adalah agar ibu mengetahui pengertian MP ASI, tahapan MP ASI, tekstur, varian dan jenis bahan makanan MP ASI serta hal-hal yang harus diperhatikan saat MP ASI. Manfaat bagi kader yaitu untuk menambah pengetahuan tentang MP ASI sehingga mampu mengarahkan ibu balita pada saat akan pelaksanaan pemberian MP ASI. Manfaat 
bagi bidan yaitu untuk menambah pengetahuan tentang MP ASI kepada masyarakat khususnya bagi ibu balita.

\begin{tabular}{l}
\hline SUBJEK DAN METODE \\
\hline Kegiatan Pengabdian kepada \\
Masyarakat ini dengan judul "Model Pem- \\
berdayaan Pada Ibu Balita tentang MP \\
ASI di Kelurahan Wonorejo". Model pe- \\
mberdayaan merupakan pada proses mem- \\
berikan kemampuan kepada masyarakat \\
agar menjadi berdaya, mendorong atau \\
memotivasi individu agar mempunyai ke- \\
mampuan atau keberdayaan untuk menen- \\
tukan pilihan hidupnya. Dalam hal ini pe- \\
mberdayaan dilakukan pada kelompok ibu \\
balita dalam hal pemberian MP ASI. Ibu \\
balita diberikan pendidikan kesehatan oleh \\
tim dan praktek bagaimana cara membuat \\
MP ASI dengan memanfaatkan bahan pa- \\
ngan yang mudah didapatkan atau berada \\
di lingkungan sekitar. Diharapkan setelah \\
mendapatkan pengetahuan tersebut ibu ba- \\
lita dapat melaksanakan selama dirumah \\
dan bayi/balita akan mendapatkan MP \\
ASI sesuai dengan tahapan perkembangan \\
dan tumbuh kembang bayi/balita tersebut \\
dapat berjalan baik sesuai dengan tahapan \\
umurnya.
\end{tabular}

\section{HASIL}

Kegiatan Model Pemberdayaan MP ASI ini berada di Kelurahan Wonorejo tepatnya dilaksanakan di Posyandu Mekar Sari yang berada di Jalan Mangga Perum Bumi Wonorejo dan dilaksanakan pada tanggal 18 dan 19 November 2018. Adapun peserta yang hadir yaitu Ibu-ibu balita, bidan PKD Wonorejo, kader dan petugas dari Kecamatan Gondangrejo. Pengisi materi pemberdayaan MP ASI dari tim pengabdi Prodi D III Kebidanan FK UNS sebanyak 3 narasumber. Sebelum pelaksaaan kegiatan, tim melakukan koordinasi awal yang dengan Kepala Kelurahan dan Bidan PKD Kelurahan Wonorejo untuk pengambilan data awal. Kegiatan selanjutnya yaitu koordinasi dengan kader-kader posyandu yang berada di wilayah PKD Wonorejo, persiapan media penyuluhan. Selanjutnya diadakan Pemberdayaan pada Ibu Balita yang pada tanggal 21 November 2018.

\section{PEMBAHASAN}

Dalam konsep pemberdayaan, menurut Prijono dan Pranarka (1996) ${ }^{(4)}$, manusia adalah subyek dari dirinya sendiri. Proses pemberdayaan yang menekankan pada proses memberikan kemampuan kepada masyarakat agar menjadi berdaya, mendorong atau memotivasi individu agar mempunyai kemampuan atau keberdayaan untuk menentukan pilihan hidupnya. Lebih lanjut dikatakan bahwa pemberdayaan harus ditujukan pada kelompok atau lapisan masyarakat yang tertinggal.

Berdasarkan definisi pemberdayaan diatas tim melakukan pemberdayaan pada kelompok ibu balita dalam hal pemberian MP ASI. Model pemberdayaan ini sesuai dengan teori Health Belief Model ${ }^{(5)}$ dimana didasarkan atas tiga faktor esensial : (1) Kesiapan individu untuk merubah perilaku dalam rangka menghindari suatu penyakit atau memperkecil risiko kesehatan; (2) Adanya dorongan dalam lingkungan individu yang memotivasi untuk merubah perilaku; dan (3) Perilaku itu sendiri. Dengan demikian dimensi-dimensi yang terdapat dalam HBM adalah: (1) Kesipaan individu untuk merubah perilaku untuk menghindari suatu penyakitatau memperkecil risiko kesehatan; (2) Dorongan dalam lingkungan individu yang membuatnya merubah perilaku; dan (3) Perilaku itu sendiri. Kesiapan individu dipengaruhi oleh: (1) Persepsi tentang kerentanan terhadap penyakit dan potensi ancaman; (2) Motivasi untuk memperkecil kerentanan terhadap penyakit; (3) Potensi ancaman; dan (4) Adanya kepercayaan bahwa perubahan perilaku akan memberikan keuntungan.

Dalam pemberdayaan ini Ibu balita diberikan pendidikan kesehatan oleh tim dan praktek bagaimana cara membuat MP ASI dengan memanfaatkan bahan pangan yang mudah didapatkan atau berada di lingkungan sekitar. Diharapkan setelah mendapatkan pengetahuan tersebut ibu 
balita dapat melaksanakan selama dirumah dan bayi/balita akan mendapatkan MP ASI sesuai dengan tahapan perkembangan dan tumbuh kembang bayi/balita tersebut dapat berjalan baik sesuai dengan tahapan umurnya.

\section{SIMPULAN DAN SARAN}

Kesimpulan yang dapat ditarik dari pelaksanaan pengabdian antara lain untuk Kelurahan Wonorejo dapat berkoordinasi dengan PKD wilayah Wonorejo dalam memantau pemberian MP ASI pada balita. Kemudian bagi kader, kader dapat membantu bidan dalam penyuluhan MP ASI di wilayah posyandu masing-masing. Peran serta masyarakat dalam hal ini yaitu masyarakat aktif dalam kegiatan posyandu yang dilaksanakan dan khusunya bagi ibu yang memiliki balita yang usianya masuk dalam kriteria pemberian MP ASI sebaiknya mengikuti prosedur pemberian MP ASI sesuai dengan tahapan umurnya

\section{DAFTAR PUSTAKA}

1. United Nations Development Program. Human Development Report 2015 Work for Human Development. 2015. United Nations Development Programme 1 UN Plaza, New York, NY 10017. USA. 2015 (accessed on 20 January 2016).

2. SDKI (Survey Demografi dan Kependudukan Indonesia). Jakarta; 2012

3. WHO. Panduan pemberian ASI. 2001

4. Pranarka, A. M. W. and Priyono, Onny S. and Centre for Strategic and International Studies. Pemberdayaan : konsep, kebijakan, dan implementasi / Onny S. Prijono dan A.M.W. Pranarka, penyunting Centre for Strategic and International Studies Jakarta; 1996

5. Endang SS. Model dan teori perilaku kesehatan. 2016. Surakarta : UNS press 